\title{
Effect of fish feed concentrate on egg production of laying hens
}

\author{
Zoya Tsoy ${ }^{1, *}$, Dmitry Adushinov ${ }^{2}$ \\ ${ }^{1}$ Primorsky State Agricultural Academy, 44, Blukhera prospect, 692525, Ussuriisk, Russia \\ ${ }^{2}$ Irkutsk State Agricultural University named A.A. Ejevskogo, 59, Timiryazeva str., 664038, Irkutsk, \\ Russia
}

\begin{abstract}
The article contains materials of scientific research on the using of fish feed concentrates in the feeding of laying hens. It has been proved experimentally that this feed concentrate has a positive effect on the egg production of laying hens of the cross Haysex White. Thus, when this supplement was included in the diet of laying hens, the following results were obtained: egg production in the experimental groups increased and were higher on $13.3 ; 15.7$ and $18.3 \%$, the amount of egg mass-on 15.9 ; 18.3 and $34.6 \%$ higher than in control group.
\end{abstract}

\section{Introduction}

Poultry farming is one of the most precocious (early) branches of animal husbandry. It makes it possible to get such food products as meat and eggs in the shortest time. Poultry farming is developing rapidly all over the world and is one of the main sources of protein. However, in Russia, according to RosPoultryUnit, poultry meat production in January 2019 decreased by $3.8 \%$ compared to January last year to 502 thousand tons in live weight, and the production of chicken eggs - by $0.4 \%$ to 3.04 billion eggs.

The main factor affecting the development of poultry farming is the feed base. For poultry, the deficiency of protein and minerals is very harmful.

The issues of rational use of fish feed and seafood waste are currently insufficiently studied in the pig industry of the Far East. However, production tasks require resolution of ways of rational use of these valuable feed products in the production of pork, taking into account specific feed conditions.

In the far Eastern region, there is an opportunity to expand the use of the species diversity of extracted bioresources and their waste from processing in the feeding of farm animals.

The Far East region has all the possibilities for realizing the genetic potential of farm animals and poultry. In Primorsky region it possible to use inexpensive seafood and waste products from their processing in feeding animals and poultry widely.

Seafood and fish products, as well as waste products from their processing, are rich in protein and minerals that are necessary to provide of animal and poultry diets all nutrients.

\footnotetext{
*Corresponding author: zoyatsoy84@mail.ru
} 
Concentrates of marine origin have antioxidant, radioprotective characteristics, increase the body's resistance to diseases, increase the immune system, and improve metabolism.[1-8]

Fish meal made from non-food fish and waste from processing of food fish, crustaceans and marine mammals and other hydrobionts is the most valuable source of protein and amino acids. It is used for the enrichment of compound feeds and for maintaining the correct balance of fatty acid and amino acid compositions, the content of raw protein, the level of calcium and phosphorus, as well as for the prevention of diseases of poultry. Fishmeal, thanks to its components, contributes to the development of vital body systems: the immune system is activated, egg production increases, the digestibility of nutrients increases, and young birds fledge better. [9-11]

Fresh fish contains almost all the vitamins that animals need. During processing, some of the vitamins that are less resistant to high temperatures are destroyed. Fish meal contains many $b$ vitamins, and varieties derived from whole fish with liver contain vitamin D.

Due to its richness in high-grade protein, calcium, phosphorus and $b$ vitamins, fish meal is widely used primarily in the preparation of combined feed for young poultry. In feed for young animals, fish meal is included in an amount of up to $10 \%$, and for older young animals - up to 5-7 \%. The use of combined feed with fishmeal can increase the weight gain and egg production of chickens by $20-25 \%$ while reducing the cost of plant feed per unit of production by $15-20 \%$. These compound feeds contribute to higher safety and increase the viability of piglets and chickens. [12-15]

Egg production is one of the important indicators used in poultry farming to determine the productivity of poultry, primarily egg and chickens. It measured by counting the annual amount of laid eggs. Hens of egg breeds usually begin lay when young individuals reach $75 \%$ of the weight of an adult bird, although other factors (breed, month of birth, conditions of detention) also have a significant impact. The most precocious chickens are those that were born in March: since during their rapid growth, the daytime increases rapidly, egg laying hens of egg breeds that were born in February-March can begin at the age of 4.5 months. Chickens that were born in late spring or summer, grow in conditions of decreasing daylight, and therefore they often begin to nest only the next year. Factors that affect egg production:

-nutrition

-bird health;

-lighting;

-breed;

-air temperature;

-the age of the hen.

The main factor influencing on egg production are breed and nutrition.

We conducted a scientific research experiment to include a fish feed concentrate in the diet of laying hens. The experiments were carried out in the farm of the Ussuriisky district of Primorsky region on the hens of the Haysex White cross.

The purpose of the research is to study the possibility of including a fish feed concentrate in the diets of laying hens.

To achieve this goal, we have formulated the following tasks:

1. To detect the optimal feeding doses in the diets of laying hens

2. To study influence of including a fish feed concentrate on the egg production of laying hens

3. To compare the economic effect of eggs production of control and experimental groups of laying hens. 


\section{Research methods}

We formed 4 groups of laying hens (control and 3 experimental) with 50 heads each using the method of analogs. Laying hens of the control group were fed the main diet adopted in the farm, the rations of the experimental groups included fish feed concentrate in a dose of 3,5 and $7 \%$ as part of the feed. The scientific experience of including a fish feed concentrate lasted 120 days ( 17 weeks). The research scheme is shown in table 1 .

Table 1. Research scheme.

\begin{tabular}{|c|c|c|c|}
\hline Group & Length of research & Amount of poultry & Diet \\
\hline control & 120 days & 50 & Basic diet (BD) \\
\hline I experimental & 120 days & 50 & BD $+3 \%$ \\
\hline II experimental & 120 days & 50 & BD $+5 \%$ \\
\hline III experimental & 120 days & 50 & BD $+7 \%$ \\
\hline
\end{tabular}

In our research, we established that fish feed concentrate had a positive effect on egg production. Total egg production for the period of the experiment is shown in table 2 .

Table 2. Total egg production $(\mathrm{n}=50)$.

\begin{tabular}{|l|l|l|l|l|}
\hline \multirow{2}{*}{$\begin{array}{l}\text { Month of egg laying / age of } \\
\text { poultry, month. }\end{array}$} & \multicolumn{4}{|c|}{ Group } \\
\cline { 2 - 5 } & control & $\begin{array}{l}\text { I } \\
\text { experimental }\end{array}$ & $\begin{array}{l}\text { II } \\
\text { experimental }\end{array}$ & $\begin{array}{l}\text { III } \\
\text { experimental }\end{array}$ \\
\hline First / 5-6 & 539 & 558 & 562 & 579 \\
\hline Second / 6-7 & 694 & 792 & 798 & 818 \\
\hline Third / 7-8 & 724 & 881 & 890 & 902 \\
\hline Fourth / 8-9 & 861 & 963 & 994 & 1034 \\
\hline Total: & 2818 & 3194 & 3244 & 3333 \\
\hline \% to control & 100 & 113,3 & 115,1 & 118,2 \\
\hline
\end{tabular}

Total egg production in the experimental groups was higher than in the control group. The largest total amount of egg was in the III experimental group and amounted to 3333 eggs for the research period, which exceeds the control by $18.2 \%$. On average, the advantage of the experimental groups ranged from $13.3 \%$ to $18.2 \%$.

The results of table 2 confirm our conclusions that the fish concentrate in the compound of combined fodder has a positive effect on the egg production of poultry, as it provides laying hens with minerals, protein, and improves metabolism.

The egg production during the experiment period is shown in table 3.

Table 3. Change in egg production and its intensity, per 1 head.

\begin{tabular}{|c|c|c|c|c|c|c|c|c|}
\hline \multirow{3}{*}{$\begin{array}{l}\text { Month } \\
\text { of egg } \\
\text { laying. } \\
\text { month }\end{array}$} & \multicolumn{8}{|c|}{ Group } \\
\hline & \multicolumn{2}{|c|}{ control } & \multicolumn{2}{|c|}{ I experimental } & \multicolumn{2}{|c|}{ II experimental } & \multicolumn{2}{|c|}{ III experimental } \\
\hline & eggs & $\%$ & eggs & $\%$ & eggs & $\%$ & eggs & $\%$ \\
\hline First & $10.78 \pm 0.45$ & 35.9 & $11.16 \pm 0.57$ & 37.2 & $11.24 \pm 0.71$ & 37.4 & $11.58 \pm 0.8$ & 38.6 \\
\hline Second & $13.88 \pm 0.77$ & 46.2 & $15.84 \pm 0.8^{* * *}$ & 52.8 & $15.96 \pm 0.66^{*}$ & 53.2 & $16.36 \pm 0.77^{*}$ & 54.5 \\
\hline Third & $14.48 \pm 0.7$ & 48.3 & $17.62 \pm 0.7^{* *}$ & 58.7 & $17.8 \pm 0.9 * *$ & 59.3 & $18.04 \pm 0.82 * *$ & 60.1 \\
\hline Fourth & $17.22 \pm 0.5$ & 57.4 & $19.26 \pm 0.6^{*}$ & 64.2 & $19.88 \pm 0.8^{* *}$ & 66.3 & $20.68 \pm 0.97 * *$ & 68.9 \\
\hline Total: & 56.36 & 47.0 & 63.88 & 53.2 & 64.88 & 54.1 & 66.66 & 55.6 \\
\hline $\begin{array}{l}\% \text { to } \\
\text { control }\end{array}$ & 100 & & 113.3 & & 115.7 & & 118.3 & \\
\hline
\end{tabular}

Where: $* * * \mathrm{P} \leq 0,1, * * \mathrm{P} \leq 0,01, * \mathrm{P} \leq 0,05$.

As a result of our research work, it was established that the most intensive growth of egg production was observed in the II and III experimental groups. The number of eggs laid 
by laying hens of the experimental groups was higher than the analogues of the control group by $13.3-18.3 \%$. On average, during the experimental period, the highest egg production was in the III experimental group and amounted to 66.66 eggs or $55.6 \%$, which is higher than the control by 10.3 eggs or $18.3 \%$.

In our research, we found that fish feed concentrate has a positive effect on egg production. The total amount of eggs was higher in experimental groups than control group. The results are shown in figure 1.

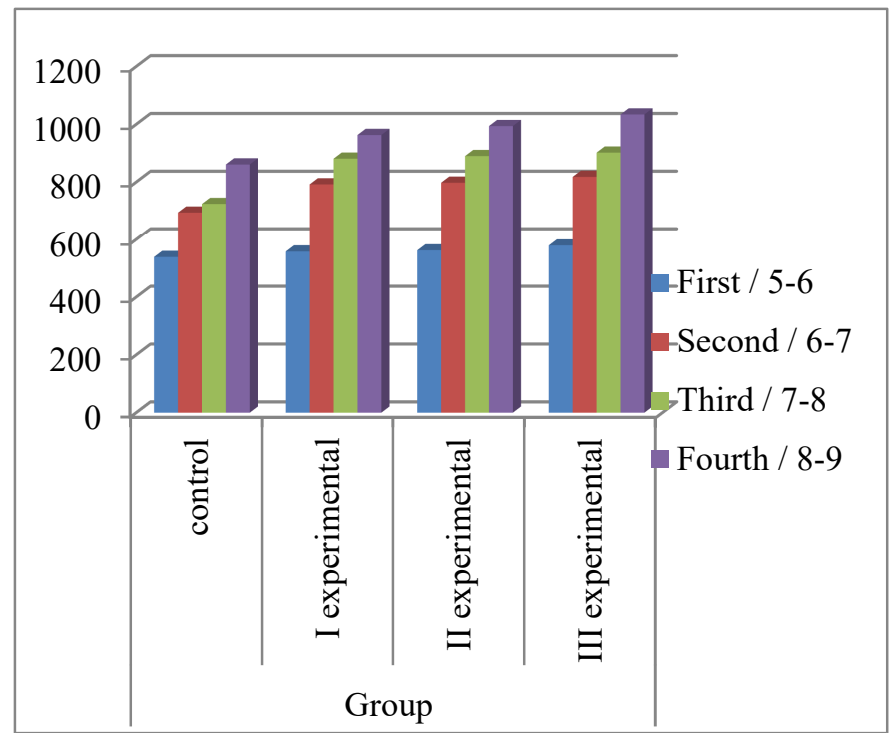

Fig. 1. Total amount of eggs.

The complex indicator of egg production is the egg mass. This indicator takes into account not only the egg productivity, but also the weight of the eggs, it can be more fully judged on egg production.

The results are presented in table 4 .

During the experiment, the largest amount of egg mass was obtained in the III experimental group, which was $219.6 \mathrm{~kg}$ or $34.6 \%$ compared to the control. Therefore, our hypothesis that this feed concentrate has a positive effect on egg production was correct, and it is optimal to include in the diet of laying hens a dose of $7 \%$ as part of the feed.

Table 4. Amount of egg mass during the experiment period $(n=50)$.

\begin{tabular}{|l|c|c|c|c|}
\hline \multicolumn{1}{|c|}{ Index } & \multicolumn{4}{|c|}{ Group } \\
\cline { 2 - 5 } & control & I experimental & II experimental & III experimental \\
\hline $\begin{array}{l}\text { Total amount } \\
\text { of eggs }\end{array}$ & 2818 & 3194 & 3244 & 3333 \\
\hline $\begin{array}{l}\text { Weight of } \\
\text { egg. g }\end{array}$ & $57.9 \pm 0.85$ & $59.2 \pm 0.77$ & $59.5 \pm 0.85$ & $65.9 \pm 0.7^{* *}$ \\
\hline $\begin{array}{l}\text { Amount of } \\
\text { eggs mass. kg }\end{array}$ & 163.16 & 189.08 & 193.02 & 219.6 \\
\hline$\%$ to control & 100 & 115.9 & 118.3 & 134.6 \\
\hline
\end{tabular}

Where: $* * \mathrm{P} \leq 0,01$.

Egg mass are shown in figure 2. 


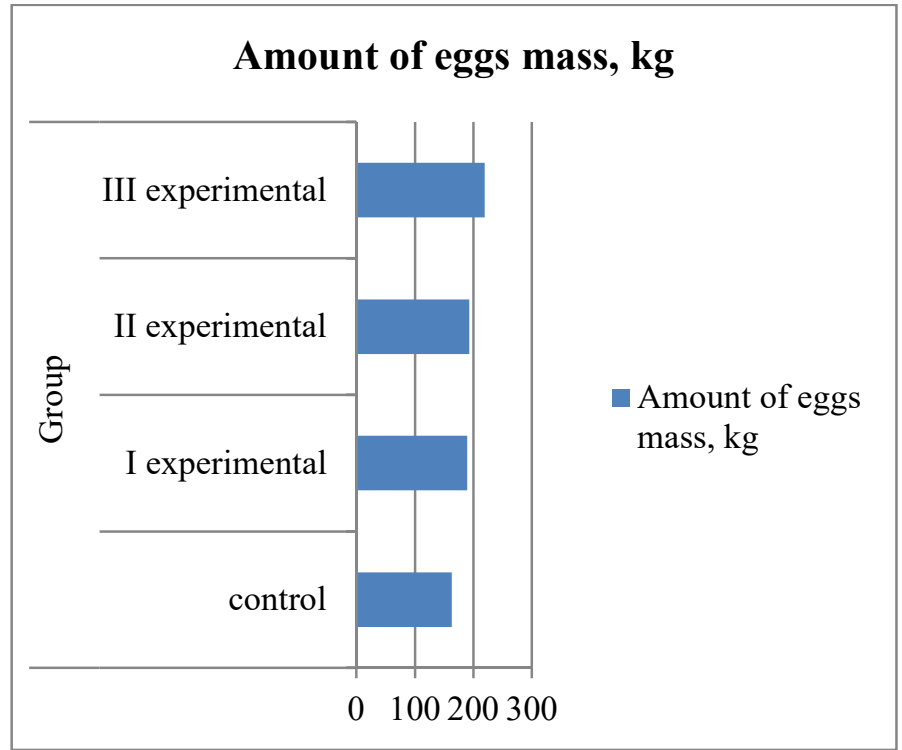

Fig. 2. Egg mass, kg.

As a result of the conducted research, it is established that the mass of eggs in the III experimental group is more than $65 \mathrm{~g}$, therefore it corresponds to the category "selected", and gives additional selling profit.

To determine the economic effect of using a fish feed concentrate, we conducted a production experiment. The production experiment was carried out in the same farm, the number of poultry was 1000 in each group, two groups were formed (control and experimental). The duration of the experiment is 60 days. The results are shown in table 5 .

Table 5. Economic results of fish feed concentrate inclusion.

\begin{tabular}{|l|c|c|}
\hline \multirow{2}{*}{\multicolumn{1}{|c|}{ Index }} & \multicolumn{2}{c|}{ Group } \\
\cline { 2 - 3 } & control & experimental \\
\hline Amount of poultry, heads. & 1000 & 1000 \\
\hline The duration of the experience, days & 60 & 60 \\
\hline Total amount of eggs & 47890 & 52385 \\
\hline Price of 1 dozen eggs, rubles. & 60 & 60 \\
\hline Profits from the sale of eggs, RUB & 287340 & 314310 \\
\hline Price of feed fish concentrate, RUB & - & 2993.8 \\
\hline $\begin{array}{l}\text { Additional profit of the farm from the inclusion } \\
\text { of concentrate, RUB. }\end{array}$ & - & 28194 \\
\hline $\begin{array}{l}\text { Additional profit of the company from the } \\
\text { inclusion of additives, rubles (per head) }\end{array}$ & - & 28.2 \\
\hline
\end{tabular}

Economic efficiency of using fish feed concentrate is shown in figure 3. 


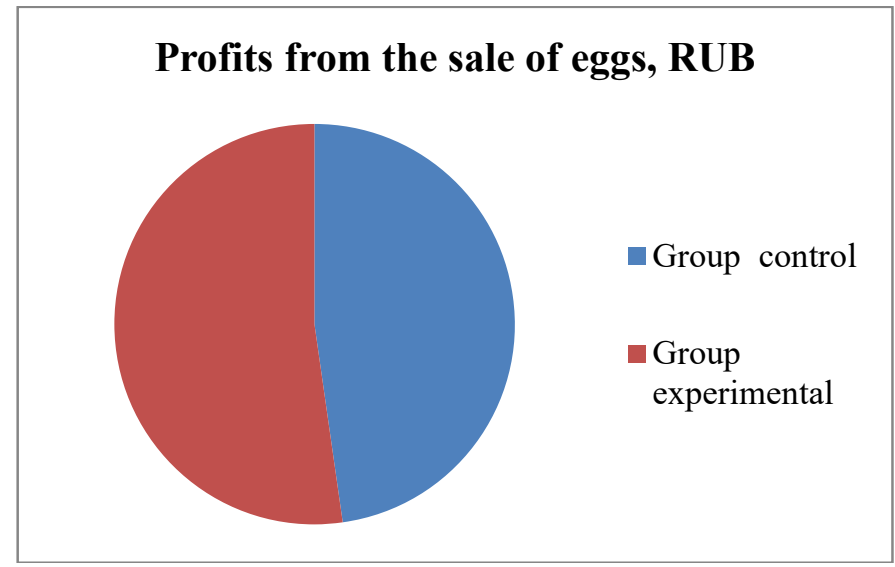

Fig. 3. Profits from the sale of eggs, RUB.

The production experiment proved that the fish feed concentrate has a positive effect on the egg production of laying hens and economic indicators. When this concentrate is included in the compound feed, the economic effect was higher on 28.2 rubles per head.

\section{References}

1. C.Y. Xue, Poult. Sci, 1164-1176 (2010)

2. E. Kiarie, Poultr. Sci, 1186-1196 (2014)

3. S.I. Kononenko, Zootechni animal science, 31-39 (2011)

4. S.I. Kononenko, Archiva Zootechnica, 13-18 (2011)

5. S.I. Kononenko, 9 International Symposium of Animal Biology and Nutrition 22 (2010)

6. T.N. Lenkova, Vestnik OrelGau, 76-80 (2013)

7. S.E. Solomon, British poultry science, 343-350 (2012)

8. R.L. Sharvadze, EurAsian Journal of BioSciences Eurasia J Biosci, 143-148 (2018)

9. T. Ondulla, Poult. Sci, 2236-2245 (2020)

10. Anupama Tiwari, Poult. Sci, 2203-2214 (2020)

11. Jia-Cai Zhang, Poult. Sci, 2026-2032 (2020)

12. Z.H. Song, Poult. Sci, 430-437 (2018)

13. Z.V. Tsoy, CIS-Korea Conference of Science and Technology, 76-83 (2015)

14. S. Vandereice, Pult. Sci, 2120-2124 (2020)

15. Z.V. Tsoy, Global Journal of Biotechnology \& Biochemistry 8(4), $74-77$ (2013) 